\title{
An Empirical Investigation of Fraud Risk Assessment and Knowledge Requirement on Fraud Related Problem Representation in Nigeria
}

\author{
Oluwatoyin Muse Johnson Popoola \\ College of Business, School of Accountancy \\ Universiti Utara Malaysia \\ Email: popoola@uum.edu.my \\ omjp0658@gmail.com \\ Ayoib Che-Ahmad, \\ College of Business, School of Accountancy \\ Universiti Utara Malaysia \\ Email: ayoib@uum.edu.my \\ Rose Shamsiah Samsudin \\ College of Business, School of Accountancy \\ Universiti Utara Malaysia \\ Email: shamsiah@uum.edu.my
}

Corresponding Author: popoola@uum.edu.my omjp0658@gmail.com 
Abstract

Purpose: The paper investigates Fraud Risk Assessment Task Performance (TPFRA) and Knowledge Requirement (KR) of the forensic accountant and auditor on Fraud Related Problem Representation (FRPR) in the Nigerian public sector.

Design/Methodology/Approach: The study used cross-sectional design and 400 Survey questionnaires. The respondents are real professional people (auditors and forensic accountants in the Nigerian public sector) as true representatives to enhance the generalisation of the outcomes. A total of 36 indicator items was measured on 5-point Likert Scale from 1 (strongly disagree) to 5 (strongly agree). PLS-SEM 2.0 3M and IBM SPSS Statistics 20.0 were employed as the primary statistical analysis tool for the study.

Findings: The results of the present study confirm the positive relationship between KR on TPFRA, positive relationship of KR on FRPR, and positive relationship of FRPR and TPFRA. Specifically, the results revealed that FRPR positively mediates the relationship between TPFRA and KR (forensic accountant and auditor) in the areas of fraud prevention, detection and response.

Research limitations/Implications: The first limitation deals with fraud and corrupt practices in a developing country, Nigeria. Examining the mediating influence of FRPR on KR and TPFRA in the public sector could be considered as sensitive and raise the issue of bias. The second limitation is the adoption of crosssectional design in which data are collected at one point in time. Researchers are encouraged to use a longitudinal design to explore interactions between KR, FRPR and TPFRA.

Practical Implication: This empirical study has revealed the value of KR (forensic accountant and auditor) as a significant capability requirement in the workplace. In addition, it shows the importance of FRPR as an important mental state in decision-making or judgement and also the significance of FRPR as an important mediating variable on KR and TPFRA

Originality/Value: No nation is immune to fraud and loss due to fraud in the public sector is enormous and costly, the result of this research will improve the KR of auditors and forensic accountants in the areas of fraud detection, prevention and response. It will also contribute to the regulatory, legal and institutional frameworks in accounting and auditing systems in Nigeria and portend an increase in demand for forensic accountants.

Keywords: fraud related problem representation, knowledge, task performance fraud risk assessment, forensic accounting, auditing, Nigeria

Type of Paper: Research Paper

JEL Code: M410 \& 420 


\subsection{Introduction}

\subsection{Background to the Study}

Nigeria, a developing nation, is blessed with an abundance of human resources, agriculture, proper climate conditions and natural resources (solid minerals, oil, hydroelectric energy, and water). Despite the abundance of these resources, the rate of economic development appears potentially slow, human resources development and provision of services; infrastructure and facilities are not sufficient. This slow pace of growth was linked to the high level of fraud, corruption, misappropriation and conversion of government properties in the public sector.

Lamorde (2012) attributed consequences of fraud to include unemployment, epileptic power supply, and the near total decay of infrastructure, bad roads, erratic water supply, inadequate hospital facilities and other social vice.

The government introduced the Fiscal Responsibility Act (FRA, 2007) and the Public Procurement Act (PPA, 2007) to curb the incidence of fraud and to promote public accountability and good governance. In spite, fraud continues to be on the increase in the public sector.

Section 85 of the Constitution of the Federal Republic of Nigeria (CFRN, 1999 as amended) provides for the Office of the Auditor-General of the Federation (OAudGF). The OAudGF acts as the government watchdog. It also reports to Public Accounts Committee (PAC) of the National Assembly (Bammeke, 2008). As noted by Popoola (2014), the delay by the PAC to meet and discuss the AudGF reports on the State financial statements is frightened. For instance, state financial statements could remain unattended to; sometimes more than three-year backlog symbolizes a gross deficiency and encourages fraud and corrupt practices in the public sector (Popoola, 2014).

It is obvious from the background to this study that corrupt practices and fraud exist in the Nigerian public service. The increase in fraud necessitates the need to carry out this study to investigate the influence of FRPR on TPFRA and KR among forensic accountants and auditors in the Nigerian public sector.

To the best of the authors' knowledge, there is no study that has examined the influence of FRPR on KR and TPFRA in the Nigerian public sector. 


\subsection{Problem Statement}

Specifically, the public outcry on fraud depicts the failure of the conventional accounting and auditing services to address and improve accountability and transparency challenges in the public governance of Nigeria. Evidence of this is the alarming rate of increase in corrupt and fraudulent practices while public services, infrastructure and facilities are fast worsening (Olumide, 2012; Ugwu, 2012).

Similarly, the public sector adopts cash basis accounting policy and relies on constitutional and regulatory frameworks. The frameworks include the CFRN, 1999 (as amended), Audit Ordinance, Finance (control and management) Act, 1958, Financial Regulations and Finance/Treasury circulars (ICAN, 2010; Bammeke, 2008). The private sector embraces the accrual basis accounting policy and complies with institutional and legal frameworks. The structures consist of accepted accounting practices (GAAP), the Nigerian Standards on Auditing (NSAs), and the Statement of Accounting Standards (SAS).

Specifically, the findings from any empirical studies conducted on private sector in Nigeria are bound to meet with gaps because of the differences that exist between private sector and public sector accounting policies. These differences cause the need to embark on this study.

\subsection{Research Questions}

1.3.1 Does Knowledge requirement (forensic accountant and auditor) relate to Task performance fraud risk assessment?

1.3.2 Does Fraud related problem representation mediates the relationship between Knowledge requirement and Task performance fraud risk assessment?

\section{$1.4 \quad$ Research Objectives}

1.4.1 To examine the relationship between Knowledge requirement (forensic accountant and auditor) and Task performance fraud risk assessment.

1.4.2 To examine the mediating influence of Fraud related problem representation on Knowledge requirement (forensic accountants and auditors) and Task performance fraud risk assessment.

\subsection{Scope of the Study}

This study considers only the office of the Accountant General of the Federation and the Auditor General for the Federation in Nigeria. Government enforcement and regulatory agencies draw from the pool of 
forensic accountants, accountants and auditors in these two offices for professional advice on fraud and financial crimes detection, prevention and response.

\subsection{Review of Literature}

\section{$2.1 \quad$ Introduction}

Consequent upon the global meltdown motivated by the the collapse of Enron, WorldCom, and Parmalat (Sarbanies-Oxley Act 2002), the global environment stresses on the procedures and controls designed by forensic accountants and auditors in the conduct of their examination in detecting, preventing and responding to fraud. Similarly, the methods embraced by statutory independent auditors and the internal auditors to plan and complete task, and to assess fraud risk in audit assignments revolve around the sensitivity of the financial statement stakeholders and the auditing and accounting standard setters. Also, the techniques used by the forensic accountants will depend on the nature, scope, evidence gathering, skills requirement, limitation to using the report and users of services and reports (Popoola, 2014).

\subsection{Definitions of Forensic Accounting and Auditing}

Popoola et al., (2013a) defined forensic accounting as the integration of specialized accounting knowledge, enhanced skills and positive mental attitude to resolving legal issues. Huber and DiGabrielle (2014) described forensic accounting as "the application of investigative and analytical skills for the purpose of resolving financial matters in a manner that meets the standards required by the court of law" (cf: Hopwood et al., 2008). Forensic accountants exist mainly for the same reasons why prosecutors and commercial branch investigators exist. The reasons were linked to the manifestation of criminals in the areas of fraud, white collar crime, corruption, money laundering, computer fraud, conversion, and theft.

Auditing is described as an unbiased examination and evaluation of the financial statements of an organization to expedite expression of opinion on its truth and fairness (Adebisi, 2011). It can be done internally (by employees of the organization) or externally (by an independent professional firm). The International Standards on Auditing No. 700 and ISA 200 provide:

"The objective of the audit of financial statements is to enable the auditor to express an opinion whether the financial statements are prepared in all material respects, in accordance with the applicable financial reporting framework"; and "the overall objectives of the Independent Auditor and the conduct of an audit in accordance with International Standards on Auditing." (IFAC, 2009a; 2009b). 
Similarly, an audit of financial statements denotes an assurance engagement as recognized in the International Framework for Assurance Engagements (IFAC, 2006b), which is considered to improve the degree of confidence of the intended stakeholders (IFAC ISA 200, section 1, para 3, p.72).

\subsection{Concept of Fraud}

Fraud is an intentional act designed principally to deceive or mislead another party (Arens \& Loebbecke, 1996), and regardless of the form fraud is noticed, it is problematic to auditors to detect since the perpetrators take steps deliberately to conceal the resulting wrongdoings (Knapp \& Knapp, 2001). In addition, fraud harms the character and the trustworthiness of the audit profession (Wuerges, 2011). Accounting researchers, practitioners, and standard setters alike uttered the concern for auditors' apparent failure in detecting fraud during an audit (Jamal, 2008; Wells, 2005; AICPA, 2002). The Association of Certified Fraud Examiner (ACFE) argues that financial statement auditors are not fraud examiner and also states that external audits are not the most efficient way to detect or limit fraud (ACFE, 2010). These viewpoints are also shared by this study based on the knowledge requirement, purpose and scope of the assignment.

Similarly, the Nigerian Standards on Auditing (NSA) No. 5, The Auditor's responsibility to consider fraud in an audit of financial statements (ICAN, 2005) and the Statement on Auditing Standards (SAS) No. 99, Consideration of Fraud in a Financial Statement Audit (AICPA, 2002 sec. 316.50) provide auditors with better guidance on how to improve their ability to detect fraud during a financial statement audit. SAS No. 99 includes the suggestion that an "auditor may respond to an identified risk of material misstatement due to fraud by assigning...forensic or IT specialists." This matter raised public awareness of fraud and forensic accounting.

\subsection{Fraud Risk Assessment Task Performance (TPFRA)}

TPFRA is designated as the focus area for this study because every ministry, department, and agency of government faces multiplicity of risks from external and internal sources. In addition, fraud risk assessment helps auditors to determine the nature and extent of audit procedures planned to increase the likelihood of uncovering fraud (Wuerges, 2011; Bloomfield, 1997). The auditing standards (AICPA SAS No. 99, 2002; AICPA SAS No. 82, 1997) specify that "auditors are to document their assessment of fraud risk during the planning phase of the audit and to update the initial evaluation as necessary throughout the course of the engagement." 
Also, the SAS No. 99 discusses relevant fraud risk factors that might signal the existence of an intentional material misstatement, that is, fraud (AICPA, 2002). The risk factors acknowledged include incentive or pressure, opportunity, and attitude or rationalization. In essence, fraud risk assessment has a direct relationship to the effectiveness of auditors' fraud detection in an audit.

Previous research in accounting has shown that much attention has been dedicated to fraud and fraud risk related issues (Allen et al., 2006; Cushing et al., 1995). Unfortunately, these studies found that auditors are poor assessors of fraud risk and as a result failed to detect fraud in financial statements (Knapp \& Knapp, 2001; Joyce \& Biddle, 1981). For this reason, it requires those in authority to consider the impact of changes in the external environment and within its activity model that may render internal control less effective.

Similarly, the O'Malley Commission recommends to the auditors to integrate fraud or forensic accounting procedures (substantive tests that were directed at the possibility of fraud) on every audit to improve the likelihood of discovering financial statement fraud (POB, 2000). Also, the Public Company Accounting Oversight Board Standing Advisory Group (SAG) highlights a number of fraud related issues that require accounting researchers' attention (PCAOB, 2008). One of the issues suggested for further research is to determine whether forensic accountants (fraud specialists or fraud examiners) are better than auditors in detecting fraud.

\subsection{Fraud Related Problem Representation (FRPR)}

Problem representation has been recognized as an internal cognitive framework that embodies an individual's understanding and interpretation of a problem situation (Bedard and Chi, 1993; Christ, 1993; Chi et al., 1981). Prior research shows that individuals develop problem representations when they are faced with a decision-making assignment (Pitz and Sachs, 1984; Gagné and White, 1978). This internal structure is constructed by mapping available problem information into individuals' existing knowledge relevant to the type of decision task they encounter (Chui, 2010; Koonce, 1993). The mapping process facilitates the construction of mental slots used to help individuals store information about their decision task (Pichert and Anderson, 1977). The way forensic accountant and auditor asserts understanding and interpretation of a fraud related problem situation depend on their knowledge requirement and fraud risk assessment. 


\subsection{Forensic Accountants and Auditors Knowledge Requirement}

Previous research has shown that both forensic accountants and auditors acquire similar fundamental knowledge (Davis, Farrell and Ogilby, 2010).

However, the ICAN in Nigeria (Popoola, 2014 p.44) and other similar professional bodies in UK, US and Canada (Huber, 2011) award forensic certification such as CFA, CFE, CFF to members after successfully completing forensic education programme. In Nigeria, one must be an ACA or FCA to be eligible for CFA education training programme. Forensic accountant applies specialized knowledge of fraud detection, prevention, deterrence and remediation structures to the fundamental knowledge in gathering information, investigation, analyzing, reporting and communicating financial information to improve future task performance judgment or to resolve legal matters (Popoola, 2014).

Without proper and adequate forensic education, expecting financial statement auditors to detect fraud is similar to pouring new wine into old bottles (Wuerges, 2011). Accounting standard setters responded to the public outcry and issued Nigerian Standards on Auditing (NSA) No. 5, and SAS No 99 (ICAN, 2005; AICPA, 2002) These standards contain recommendation that the "auditor may respond to an identified risk of material misstatement due to fraud by assigning the forensic or IT specialists" (Popoola et al., 2013b; Chui, 2010; AICPA, 2002).

Davia (2000) found that fraud detection is distinct from the financial statement audit, and it requires a diverse knowledge area, which can only be carried out through forensic accounting techniques. Prior studies have shown the necessary forensic accounting knowledge to include professional responsibilities and practice management, laws, ..... experts and testimony (Davis et al., 2010; Durkin and Ueltzen, 2009). The AICPA core wheel specialised knowledge of fraud prevention, detection and response is the focus of this study (Davis et al., 2010; AICPA, 2008).

Specifically, forensic accountants will continue to be in high demand (Wells, 2005) as long as criminals exist in the areas of fraud, corruption, asset misappropriation and conversion. This study aligns with Wells (2005) position that as long as untrained graduates are employed to detect fraud committed by technologically advanced criminals, the necessity for forensic accountants with fraud knowledge will continue to be on the increase. 


\subsection{Hypothesis Development based on Literature Review}

\subsection{Knowledge Requirement and Task Performance Fraud Risk Assessment}

Prior literature argued that the Knowledge requirement of the auditor is limited in terms of the nature and scope of the audit assignment. The International Education Standard (IES) No. 8, Competence requirements of professional accountants sections $36-41$ classified the knowledge content of the auditor into three distinct levels (IFAC-IES, 2006a). These are historical financial information audit at a higher standard, financial accounting and reporting at a higher standard, and information technology (IFAC-IES, 2006). Indeed, Statement of Auditing Practice No. 30 recognises that auditors should be conscious of the prospect of fraud presence during an audit; this was not absolutely definite and left auditors with no commitment to detect fraud (Wuerges, 2011; Albrecht and Willingham, 1993).

Literature acknowledged the fact that individuals who are educated in the use of information technology, legal, investigative, criminology, psychology and accounting will exude brilliance than others in the areas of accounting records, gathering and evaluating financial statement evidence, interviewing all parties related to an alleged fraud situation, and serving as an expert witness in a fraud case (Wuerges, 2011; Hopwood et al., 2008; Singleton et al., 2006).

This study also agrees with Daniel and Lee (2006) that other accountants may look at the charts, but forensic accountants dig deep into the body. For this reason, the following hypothesis is proposed:

H1: There is a positive direct relationship between Knowledge requirement (forensic accountant and auditor) and Task performance fraud risk assessment.

\subsection{Knowledge Requirement and Fraud Related Problem Representation}

The second theoretical relationship in this research framework epitomizes the impact of Knowledge requirement (KR) on the Fraud related problem representation (FRPR). KR has indirect influences on decision-making task performance through the development of an emotional structure that is mostly referred to as FRPR (Kleinman and Palmon, 2007; Gupta and Govindarajan, 2002).

Prior studies have made available empirical evidence to argue the assertion that KR influences the development of individuals' FRPR, which in turn inspire their task performances (Chui, 2010; Torelli and Kaikati, 2009). This study asserts that there is a significant relationship between KR and FRPR. The hypothesis is formulated thus:

H2: There is a positive direct relationship between KR (forensic accountant and auditor) and FRPR. 


\subsection{Fraud Related Problem Representation and Task Performance Fraud Risk Assessment}

Prior study has shown that the Fraud related problem representation (FRPR) has a consequential impact on individual's judgment and decision-making (Kadous and Sedor, 2004). Also, Bierstaker et al., (1999) study that investigate auditors' problem representation and their performance on analytical procedure job using a think-aloud verbal protocol to elicit auditors' problem representation about their clients' allocation of overhead costs lend weight to Kadous and Sedor (2004) study.

Based on the above discussion, this study asserts that there is a significant relationship between FRPR and TPFRA. The formulated hypothesis is:

H3: There is a positive direct relationship between Fraud related problem representation and Task performance fraud risk assessment.

\subsection{Mediating Hypothesis}

As stated in Hypotheses H1, H2, and H3, there is positive significant direct relationship between KR and TPFRA, a positive significant direct link between KR and FRPR, and a positive significant direct relationship between FRPR and TPFRA. For this reason, this study affirms that FRPR mediates the relationship between KR and TPFRA. It is hypothesized:

H4: $\quad$ FRPR positively mediates the relationship between KR and TPFRA

\subsection{Conceptual Framework}

Figure 1 summarizes earlier literature and illustrates the conceptual framework of TPFRA on KR and FRPR in the Nigerian public sector.

\section{INSERT FIGURE 1}

Figure 1 Theoretical Framework: Mediating effect of FRPR on KR and TPFRA model

\subsection{Methodology}

\subsection{Introduction}

This study embraced the positivist ontology, empirical epistemology, and quantitative methodology. Remenyi et al., (1998) asserted that a methodological framework could be derived from a review of the relevant literature, which provides the researcher with a clear expectation of how a particular phenomenon is likely to behave, and from which a researcher formalises a model. 


\subsection{Research Design}

The study used Cross-sectional design as data were collected at a single point in time. The meaning of research design is to give weight to the evidence acquired to enable the researcher to answer the research questions as unequivocally as possible (De Vaus, 2011).

\subsection{Population, Survey Questionnaire, Pilot Study \& Measures of Variables}

The study respondents are forensic accountants and auditors in the accounting and auditing institutions of the Nigerian public sector. Prior to the conduct of a pilot study, the survey questionnaire was subjected to expert review (content validity). Their comments and suggestions were also recognized. Pilot study was carried out on 60 respondents, out of which 12 suffered rejection as unusable.

400 survey questionnaires were distributed in a random sample of forensic accountants and auditors in the office of the Accountant General of the Federation and Auditor General for the Federation.

The research respondents were asked the extent of their agreement with the 7 items of Knowledge requirement (Davis et al., 2010; Ramaswamy, 2007, 2005), 16 items of Fraud related problem representation (Basadur, Basadur and Licina, 2013; Basadur \& Basadur, 2011) and 4 items of Task performance fraud risk assessment (Dzomira, 2014; Owens, 2012). The agreement ratings was made on a 5-point Likert scale for KR and TPFRA ranging from 1 (Strongly disagree) to 5 (Strongly agree). Also, the FRPR consisted of 16 items on a 5-point Likert scale ranging from 1 (Not at all) to 5 (Very often).

\subsection{Data Analysis}

Descriptive statistics (ranges, means, and standard deviations) was computed with the use of IBM SPSS (Version 20.0) (Coakes, 2013; Pallant, 2010). In addition, Partial Least Square Structural Equation Modelling (PLS-SEM), a statistical analysis tool was employed for the reflective measurement model and structural model (Hair, et al., 2014).

\subsection{Results}

\subsection{Response Rate \& Descriptive Statistical Analysis}

A total of 267 (66.75\%) individuals completed the survey. 234 (58.5\%) respondents were found to be usable to further analysis and $33(8.25 \%)$ were rejected for multiple tickings and non-completion of the survey questionnaire. Of the 234 that were usable, 129 (55\%) were forensic accountants and 105 (45\%) were auditors. 
Descriptive statistics for the Knowledge requirement, Fraud related problem representation and Task performance fraud risk assessment, is shown in TABLE 1.

\section{INSERT TABLE 1}

Range, Mean and Standard Deviations of Respondents ( $\mathrm{N}=234)$

Knowledge requirement construct recorded the highest scores $(\mathrm{M}=4.75, \mathrm{SD}=0.42)$, whilst the lowest score obtained by the Fraud related problem representation construct $(\mathrm{M}=4.34, \mathrm{SD}=0.64)$.

\subsection{Evaluation of Results}

This study employs Partial least square structural equation modelling analysis in the assessment of the measurement model (reflective) and the structural model. Reflective measurement model comprises internal consistency (composite reliability), indicator reliability, convergent validity (average variance extracted), and discriminant validity (Hair et al., 2014). Also, structural model evaluation consists of coefficient of determination $\left(\mathrm{R}^{2}\right)$, predictive relevance $\left(\mathrm{Q}^{2}\right)$, size and significance of path coefficients, and $\mathrm{f}^{2}$ effect sizes (Hair et al., 2014; Barclay et al., 1995).

Chin (2010) found out that the old-fashioned parametric-based techniques for significance testing were not appropriate in PLS-SEM because of its non-distributional normality assumption of the observations in estimating parameters. In this study, Table 2 has shown that all outer loadings of the constructs KR, FRPR and TPFRA are well above the minimum acceptable level for outer loadings $0.5\left(0.708^{2}\right)$.

\section{INSERT TABLE 2}

Key Factor loadings and Cross loadings

Also, in the evaluation of the measurement model, Table 3 summarizes the model quality criteria convergent validity and reliability analysis. Similarly, the composite reliability (CR) values of 0.95 (KR), 0.93 (FRPR), and 0.95 (TPFRA) illustrate that all the three constructs have high levels of internal consistency reliability.

In this study, the AVE values of KR (0.82), FRPR (0.68), and TPFRA (0.82) are well above the minimum level of 0.50 . Hence, the measures of the three reflective constructs have a high degree of convergent validity (Hair et al., 2014).

INSERT TABLE 3

Model Quality Criteria: Convergent Validity and Reliability Analysis 
According to Hair, Ringle, \& Sarstedt (2011), any cross-loadings that exceed the indicators' outer loadings portends a discriminant validity problem. The outer loadings of FRPR13 (0.854), KR1 (0.940), and TPFRA1 (0.906) show greater loadings than all of their loadings on other constructs, that is, the cross-loadings (Table $2 \&$ Table 3 ).

The square root of the AVE values and the latent variable correlations was compared in adherence to the Fornell-Lacker (1981) criterion (Hair et al., 2010). The logic behind the conservative approach indicates that a construct shares more variance with its associated indicators than with any other construct.

\section{INSERT TABLE 4}

Correlations and Discriminant Validity

\section{INSERT FIGURE 3}

PLS-SEM Algorithm Direct Effects Results: KR on TPFRA, KR on FRPR and FRPR on TPFRA

Hair et al., (2014) found that PLS-SEM fits the model to the sample data to obtain the best parameter estimates by maximising the explained variance of the endogenous latent variable(s). There are two hypotheses that were formulated to answer the research questions highlighted in 1.3. Figure 4 represents the essential criteria for assessment of the structural model.

\section{INSERT FIGURE 4}

Results of the Bootstrapping Structural Model

\subsection{Evaluating $R^{2}$ of the Model}

The $\mathrm{R}^{2}$ denotes the amount of explained variance of the Task performance fraud risk assessment construct of the structural model. Prior research has shown that a well-developed path model should deliver sufficiently high $\mathrm{R}^{2}$ values to describe Knowledge requirement construct. This study recorded $\mathrm{R}^{2}$ values of 0.42 (medium) and 0.80 (substantial) for Fraud related problem representation and Task performance fraud risk assessment respectively, thus establishing substantial amount of explained variance according to Chin (2010) and Albers (2010) baseline criteria of 0.25 (weak), 0.50 (medium), and 0.75 (substantial).

\subsection{Evaluating effect size $f^{2}$ values in the structural model}

The $\mathrm{f}^{2}$ effect size captures the contribution of Knowledge requirement construct to the $\mathrm{R}^{2}$ value of Task performance fraud risk assessment construct of the structural model. The guidelines for evaluating $\mathrm{f}^{2}$ are that values of $0.02,0.15$, and 0.35 respectively represent small, medium, and large effects (Cohen, 1988) 
of the endogenous latent variable. Table 5 describes the evaluation of $\mathrm{f}^{2}$ effect size on the structural model of this study.

\section{INSERT TABLE 5}

Assessing $\mathrm{f}^{2}$ effect sizes of the Structural Model

The Task performance fraud risk assessment recorded $\mathrm{f}^{2}$ effect size of Knowledge requirement (0.20), which belongs to a medium effect size. This size confirms the evaluation criteria to have been met. It also demonstrated the contribution of the Knowledge requirement construct to the target construct of Fraud related problem representation.

\subsection{Evaluating the Predictive Relevance $Q^{2}$ of the Structural Model}

The study examines the $Q^{2}$ predictive relevance value based on Geisser (1974) and Stone (1974). Literature has shown that when the SEM-PLS exhibits predictive significance, it accurately predicts the data points of indicators in reflective measurement model of endogenous constructs (Hair et al., 2014). Similarly, the $\mathrm{Q}^{2}$ values larger than zero show the path model's predictive relevance for TPFRA. For this study, the $\mathrm{Q}^{2}$ value is obtained by using the blindfolding procedure for a set distance $\mathrm{D}$ of 7 , (Hair et al., 2014), and as represented in Table 6

\section{INSERT TABLE 6}

Assessing the predictive relevance of $\mathrm{Q}^{2}$ values in the structural model

The TPFRA construct evaluation specifies $Q^{2}$ effect size of KR (0.04) as belonging to a small effect size by a confirmation that the assessment criteria to have been considered in line with Cohen's (1988) criteria.

\subsection{Direct Hypothesis}

\section{INSERT TABLE 7}

Direct relationship effects of KR and FRPR on TPFRA

This Table 7 and Figure 4 indicate direct relationships between KR, FRPR and TPRA and signify three circumstances. First, the result shows that KR maintained significant association with: a) TPFRA (beta = $0.085 ; \mathrm{t}=2.238 ; \mathrm{p}=0.000$ ), and $\mathrm{b}$ ) FRPR (beta $=0.648 ; \mathrm{t}=17.435 ; \mathrm{p}=0.000$ ). Also, a very strong relationship between FRPR and TPFRA (beta $=0.949 ; \mathrm{t}=31.409 ; \mathrm{p}=0.000$ ). The results highlight that among the two criterions of KR, FRPR recorded the highest significant path coefficient (beta $=0.648$ ). 
This explains KR contribution as the most significant predictor of FRPR and TPFRA of forensic accountants and auditors in the Nigerian public sector. Consequently, the hypotheses - H1, H2 and H3 are well supported and accepted by this study.

\subsection{Mediation Hypothesis}

Table 8 demonstrates the indirect relationship of FRPR on KR, and TPFRA through the path coefficient, the standard error, the $t$ values, the $p$-values of the PLS-SEM structural model and the decision adopted.

\section{INSERT TABLE 8}

PLS-SEM Mediation and Bootstrap of the Indirect hypothesised path

The study employed multiple regression analyses to assess each component of the mediation model. First, it was found that KR was positively associated with TPFRA (beta $=.85, \mathrm{t}(232)=22.030, \mathrm{p}=.000$ ). Second, it was also established that KR was positively related to FRPR (beta $=.75, \mathrm{t}(232)=16.811, \mathrm{p}=$ .000 ). Third and last, the mediator, FRPR was positively related to TPFRA (beta $=.68, \mathrm{t}(232)=13.032, \mathrm{p}$ $=.000$ ). Results confirmed the mediating role of FRPR on the relationship between KR and TPFRA (beta $=.51, \mathrm{CI}=.42$ to .61$)$. Also, the results indicated the direct effect of KR on TPFRA to be significant (beta $=.52, \mathrm{t}(232)=9.784, \mathrm{p}=.000)$ when controlling for FRPR. It suggests partial mediation. Thus, hypothesis 4 and as demonstrated in TABLE 8, and Figure 5 of this study is supported.

\section{INSERT FIGURE 5}

FRPR on the influence of KR and TPFRA

\subsection{Discussions}

\subsection{Introduction}

In this study, Task performance fraud risk assessment describes the ability of the forensic accountant and the auditor to assess the risk of fraud to a defined level in the real working environment. This study found that in relation to accounting and auditing profession, Knowledge requirement and Fraud related problem representation have significant relationships with Task performance fraud risk assessment.

Knowledge requirement refers to the attribute and proficiency competences of the forensic accountant and the auditor necessary to discharge technical and innovative task with respect to fraud prevention, detection and response (Popoola et al., 2013a). The current findings provide support for the hypothesis H1 and also agree with the previous research of Davis et al., (2010) that found a positive relationship. 
The result in knowledge development would correspondingly upturn their proficiency competences; create awareness and understanding of the fraud schemes.

Fraud related problem representation is described in this study as an internal cognitive framework that embodies an individual's understanding and interpretation of a problem situation (Greeno, 1977; Chi et al., 1981), especially in fraud prevention, detection and response (Popoola et al., 2013b; Chui, 2010). The finding provides support for the hypothesis $\mathrm{H} 2$ and agrees with the previous research (Chui, 2010) that found a positive relationship.

Task performance fraud risk assessment is the substratum of the audit assignment. The finding provides support for the hypothesis H3 and agrees with the previous study of Chui (2010) that found a positive relationship between Fraud related problem representation and Task performance fraud risk assessment.

Importantly, the result of the mediating effect represents the significant contribution of this study. The findings provide support for this hypothesis $\mathrm{H} 4$.

\subsection{Contributions/Implications of the Study}

\subsubsection{Theoretical contributions}

1. This study expanded the task performance fraud risk assessment literature within the organizational context in a developing country, Nigeria;

2. It also established the mediating influence of fraud related problem representation on the relationship between knowledge requirement (forensic accountant and auditor) and task performance fraud risk assessment;

3. The study confirmed the positive influence of Fraud related problem representation on Task performance fraud risk assessment;

4. This study proved the positive influence of knowledge (forensic accountant and auditor) on fraud related problem representation; and

5. It established the significant positive direct relationship of Knowledge requirement on Task performance fraud risk assessment. 


\subsubsection{Methodological Contributions}

1. The study adopted quantitative research with Cross-sectional design that is unique in having more successes than other designs towards achieving representativeness in order to generalize the results obtained in a sample of the wider population the sample represents;

2. The use of respondents who are real professional people (forensic accountant and auditor) instead of student surrogates; and

3. The use of PLS-SEM Algorithm and Bootstrapping statistical analysis techniques provide prospect for testing the robustness and predictive power of the tool in exploratory relationships of the constructs and also because of the ever increasing importance of understanding latent phenomena such as attitudes, attributes, consumer perceptions, or intentions as well as their impact on organisational performance measures (Hair et al., 2014; Kline, 2005; Hershberger, 2003).

\subsubsection{Managerial/Practical}

1. This study revealed the value of knowledge (forensic accountant and auditor) as a significant capability requirement in the workplace;

2. It showed the importance of fraud related problem representation as a mental representation in understanding and interpretation of a task performance in the workplace;

3. The study revealed the significance of Task performance fraud risk assessment as a primary competence requirement in the areas of fraud detection, prevention/deterrent and response;

4. It also explained the importance of fraud related problem representation as a significant mediating variable on knowledge (forensic accountant and auditor) and task performance fraud risk assessment;

5. The study has the potentials to contribute to the regulatory, institutional and legal framework in the accounting and auditing systems in Nigeria. 


\subsection{Limitations and Future Research}

The first limitation of this research deals with fraud and corrupt practices in a developing country, Nigeria. Examining the mediating influence of FRPR on KR and TPFRA in the public sector could be considered as sensitive and raise the issue of bias. The second limitation is the adoption of cross-sectional design in which data are collected at one point in time.

Future research could include professional ethics. Ethics is significant in order for the profession to make available excellent services in the areas of fraud prevention, detection and response. Ethics (forensic accountant and auditor) can serve as a mediator in a model involving KR and TPFRA.

\subsection{Conclusion}

This study presented a detailed analysis of the mediating impact of FRPR on TPFRA and KR requirement (forensic accountant and auditor) in the Nigerian public sector. Although, TPFRA has been widely researched, most of the attempts are fragmented and in piecemeal (Davis et al., 2010; Wuerges, 2011; Chui, 2010). It also examined the relationship between KR and TPFRA, the relationship between KR and FRPR and the relationship between the FRPR and TPFRA beyond the ordinary scope of western countries. The findings confirmed that FRPR did influence TPFRA. The current study listened to the clarion calls to examine auditor's inability to detect and prevent fraud (Chui, 2010; Davis et al., 2010; Boritz et al., 2008; Knapp \& Knapp, 2001) and the PCAOB (2004) recommendation for future research as to whether forensic accountants are capable and competent than auditors in detecting fraud.

This study provided, perhaps for the first time, analysis of the relationship between Knowledge requirement and Task performance fraud risk assessment by integrating the mediating influence of Fraud related problem representation. It also created consciousness of fraud schemes among the auditors and accountants in the Nigerian public sector. This can be achieved through training and acquisition of forensic accounting knowledge amongst others.

Lastly and in agreement with Houck et al., (2006) study, fraud and forensic accounting affect the accounting profession every day and it is the responsibility of the State to design appropriate procedures and controls that will usher in a systematic reduction in fraud. 


\section{References}

ACFE. 2010. Report to the Nations on Occupational Fraud and Abuse. Association of Certified Fraud Examiners. Austin, TX: ACFE.

Adebisi, F. A. 2011. Audit, Investigation and Forensics: Similarities and Differences. Institute of Chartered Accountants of Nigeria: Forensic, Audit \& Investigation Faculty, February.

AICPA. 1997. Statement on Auditing Standards (SAS) No. 82: Consideration of Fraud in a Financial Statement Audit (American Institute of Certified Public Accountants, Durham).

AICPA. 2002. American Institute of Certified Public Accountants. Statement on Auditing Standards (SAS) No. 99, Consideration of Fraud in a Financial Statement Audit (AICPA, Professional Standards, vol. 1, AU Sec. 316.50).

AICPA. 2008. Forensic and Valuation Services: Overview of Certified in Financial Forensics (CFF) Credential (American Institute of Certified Public Accountants, Durham. Retrieved September, 2009, from http://fvs.aicpa.org/Memberships/ Overview+of+Certified+in+Financial+Forensics+Credential. Htm

Albers, S. 2010. PLS and success factor studies in marketing, In: Esposito Vinzi, V., Chin, W.W., Henseler, J., Wang, H. (Eds.), Handbook of Partial Least Squares: Concepts, Methods and Applications (Springer Handbooks of Computational Statistics Series, vol. II). Springer, Heidelberg, Dordrecht, London, New York, pp. 409-425.

Albrecht, W.S. \& Willingham, J.J. 1993. "The Auditors Responsibility to Detect and Report Errors and Irregularities", In The Expectation Gap Standards - Progress, Implementation Issues, Research Issues, New York, American Institute of Certified Public Accountants.

Allen, R. D., Hermanson, D. R., Kozloski, T. M., \& Ramsay, R. J. 2006. "Auditor Risk Assessment: Insight from the Academic Literature." Accounting Horizons 20 (2): 157-177.

Arens, A., \& Loebbecke, J. 1996. Auditing: an integrated approach. (6th Ed.) Prentice Hall, Englewood Cliffs, NJ.

Bammeke, S. A. 2008. Public Sector Accounting and Finance for Decision Making. Lagos, Sab \& Associates Limited.

Barclay, D., Higgins, C., \& Thompson, R. 1995. The partial least squares (PLS) approach to causal modelling. Technology Studies, 2, 285-323.

Basadur, M., Basadur, T., \& Licina, G. 2013. Simplexity Thinking. Encyclopedia of Creativity, Invention, Innovation and Entrepreneurship, 1617-1634.

Basadur, M., \& Basadur, T. 2011. Where are the generators?. Psychology of Aesthetics, Creativity, and the Arts, 5(1), 29.

Bedard, J., \& Chi, M. T. H. 1993. "Expertise in Auditing." Auditing: A Journal of Practice and Theory 12 (Supplement): 21-45. 
Bierstaker, J. L., Bedard, J. C., \& Biggs, S. F. 1999. "The Role of Problem Representation Shifts in Auditor Decision Processes in Analytical Procedures." Auditing: A Journal of Practice and Theory 18 (1): 18-36.

Bloomfield, R. J. 1997. Strategic Dependence and the Assessment of Fraud Risk: A Laboratory Study: The Accounting Review, Vol. 72, No. 4, p. 517-538

Boritz, J. E., Kotchetova, N., \& Robinson, L. A. 2008. "Planning Fraud Detection Procedures: Fraud Specialists vs. Auditors." Working Paper: University of Waterloo.

Chi, M. T. H., Feltovich, P. J., \& Glaser, R. 1981. "Categorization and Representation of Physics Problems by Experts and Novices." Cognitive Science 5: 121-152.

Chin, W. W. 2010. How to write up and report PLS analyses. In Esposito, V., et al. (eds.), Handbook of Partial Least Squares (pp. 655 - 688). New York: Springer-Verlag.

Christ, M. Y. 1993. "Evidence on the Nature of Audit Planning Problem Representations: An Examination of Auditor Free Recalls." The Accounting Review 66 (2): 304-322.

Chui, L. 2010. An experimental examination of the effects of fraud specialist and audit mindsets on fraud risk assessments and the development of fraud-related problem representation. ProQuest LLC, UMI 3436520, 789 East Eisenhower Parkway, USA.

Coakes, S. J. (2013). SPSS: Analysis without anguish: version 20.0 for Windows. John Wiley \& Sons Australia, Ltd. Milton, Qld 4064.

Cohen, J. 1988. Statistical Power Analysis for the Behavioural Sciences, 2nd ed. Lawrence Erlbaum Associates, Hillsdale, NJ.

Cushing, B. E., Graham, L. E., Palmrose, Z. V., Roussey, R. S., \& Solomon, I. 1995. "Risk Orientation.” In Bell, T. B., \& Wright, A. M. (Ed.), Auditing Practice, Research, and Education: A Productive Collaboration (pp. 11-54). New York, NY: American Institute of Certified Public Accountants, Inc.

Daniel, A. \& Lee, B. 2006. Forensic Accountants appearing in the Literature. Retrieved March 10, 2012 at www.bus.lsu.edu/accounting/faculty/lcrumbley/forensic.html

Davia, H. R. 2000. Fraud 101: Techniques and Strategies for Detection. New York, NY: John Wily and Sons, Inc.

Davis, C., Farrell, N., \& Ogilby, S. 2010. Characteristics and Skills of the Forensic Accountant. American Institute of Certified Public Accountants FVS Section

De Vaus, D. A. 2011. Research Design in Social Research. Sage Publications Ltd, London.

Durkin, R., \& Ueltzen, M. 2009. The Evolution of The CFF Credential, The Practicing CPA, July/August.

Dzomira, S. 2014. Internal Controls and Fraud Schemes in Not-For-Profit Organisations: A Guide to Good Practice. Research Journal of Finance and Accounting, 5(2), 118-126.

Fornell, C., \& Larcker, D. F. 1981. Evaluating structural equation models with unobservable and measurement error. Journal of Marketing Research, 18, 39- 50. 
Gagné, R. M., \& White, R. T. 1978. "Memory Structures and Learning Outcomes." Review of Educational Research 48 (2): 187-222.

Geisser, S. 1974. A predictive approach to the random effects model. Biometrika, 61, 101-107.

Greeno, J. G. 1977. "Process of Understanding in Problem Solving." In Castellan, N. J., Pisoni, D. B., \& Potts, G. R. (Ed.), Cognitive Theory. Vol. 2. (Pp. 43-82). Hillsdale, NJ: Lawrence Erlbaum Associates, Publishers.

Gupta, A. K., \& Govindarajan, V. 2002. "Cultivating a Global Mindset." Academy of Management Executive 16 (1): 116-126.

Hair, J. F., Hult, G. T. M., Ringle, C. M., \& Sarstedt, M. 2014. A Primer on Partial Least Squares Structural Equation Modeling (PLS-SEM). Sage, Thousand Oaks.

Hair, J. F., Ringle, C. M., \& Sarstedt, M. 2011. PLS-SEM: Indeed a silver bullet. Journal of Marketing Theory and Practice 19 (2), 139-151.

Hair, J. F., Jr., Black, W. C., Babin, B. J., Andersen, R. E., \& Tatham, R. L. (2010). Multivariate data analysis (7th Ed.). Upper Saddle River, NJ: Pearson Prentice Hall.

Hershberger, S. L. (2003). The growth of structural equation modeling. Structural Equation Modeling 10 (1): 35-46.

Hopwood, W. S., Leiner, J., \& Young, G. R. 2008. Forensic Accounting. New York, NY: McGrawHill/Irwin.

Houck, M. M., Kranacher, M., Morris, B., Robertson, J., \& Wells, J. T. 2006. Forensic Accounting as an Investigative Tool. The CPA Journal, August $1 .$.

Huber, W. D. 2011. Forensic Accountants, Codes of Ethics and Forensic Accounting Corporations. Paper presented to the Southeast Section of the American Accounting Corporation, Destin, Florida, March 26.

Huber, W. D. \& DiGabrielle, J. A. 2014. Research in Forensic Accounting - What Matters? Journal of Theoretical Accounting Research, 10(1), 40-70, 2014. Available at SSRN: http://ssrn.com/abstract=2417402. Retrieved February 12.

ICAN. 2005. Nigerian Standards on Auditing (NSA) No. 5: The Auditor's Responsibility to Consider Fraud in an Audit of financial statements. Institute of Chartered Accountants of Nigeria (ICAN). Lagos, Nigeria

ICAN. 2010. The Institute of Chartered Accountants of Nigeria Public Sector Accounting Study Pack. VI Publishers, Lagos, Nigeria.

IFAC. 2006a. International Accounting Education Standard Board (IES 8, 2006). Competence Requirements for Audit Professionals. International Federation of Accountants.

IFAC. 2006b. International Framework for Assurance Engagements. International Federation of Accountants. 
IFAC. 2009a. International Standard on Auditing (ISA) No. 700: "Forming an Opinion and Reporting on Financial Statements. International Federation of Accountants.

IFAC. 2009b. International Standard on Auditing (ISA) No. 200: "Overall Objectives of the Independent Auditor and the Conduct of an Audit in Accordance with International Standards on Auditing." International Federation of Accountants.

Jamal, K. 2008. "Mandatory Audit of Financial Reporting: A Failed Strategy for Dealing with Fraud." Accounting Perspectives 7 (2): 97-110.

Joyce, E., \& Biddle, G. 1981. “Anchoring and Adjustment in Probabilistic Inference in Auditing.” Journal of Accounting Research 19: 120-145.

Kadous, K., \& Sedor, L. 2004. "The Efficacy of Third-Party Consultation in Preventing Managerial Escalation of Commitment: The Role of Mental Representations." Contemporary Accounting Research 21 (1): 55-82.

Kleinman, G., \& Palmon, D. 2007. Ability, Cognitive Fallibility, Procedural Instrumentality and Audit Group Judgment: An Exploration. Working Paper: Touro College.

Kline, R. B. (2005). Principles and practice of structural equation modelling. 2nd ed. New York: The Guilford Press.

Knapp, C. A., \& Knapp, M. C. 2001. "The Effects of Experience and Explicit Fraud Risk Assessment in Detecting Fraud with Analytical Procedures." Accounting, Organizations and Society 26: 25-37.

Koonce, L. 1993. "A Cognitive Characterization of Audit Analytical Review." Auditing: A Journal of Practice and Theory 12 (Supplement): 57-76.

Lamorde, I. 2012. "Nigeria: More boost for corruption". A paper presentation on the EFCC Budget Defence at the Senate Chamber, Federal Republic of Nigeria. Vanguard Newspaper, November 27.

Olumide, O. (2012). KPMG Nigeria: Africa Fraud Barometer Result. (Headline) ThisDay Newspaper, November 23.

Owens, D. R. 2012. Fraud Risk Assessment Practices and Corporate Governance.

PCAOB. (2004). Standing Advisory Group Meeting: Financial Fraud (September 8-9). Public Company Accounting Oversight Board. Retrieved November 20, 2008, from http://www.pcaobus.org/Standards/Standing_Advisory_Group/Meetings/2004/09-08/Fraud.pdf.

PCAOB. 2008. Public Company Accounting Oversight Board. Standing Advisory Group. Retrieved December 2, 2008, from http://www.pcaobus.org/Standards/Standing_Advisory Group/index.aspx

Pallant, J. (2010). SPSS Survival Manual: A step by step guide to data analysis using SPSS. 4th Ed. McGraw Hill.

Pichert, J. W., \& Anderson, R. C. 1977. "Taking Different Perspectives on a Story." Journal of Educational Psychology 69 (4): 309-15. 
Pitz, G. P., \& Sachs, N. J. 1984. "Judgment and Decision: Theory and Application.” Annual Review of Psychology 35: 139-163.

POB. 2000. Panel on Audit Effectiveness Report and Recommendations. Public Oversight Board. Stamford, CT: POB.

Popoola, O. M. J. 2014. Forensic Accountants, Auditors and Fraud: Capability and Competence Requirements in the Nigerian Public Sector. A thesis submitted to the Othman Yeop Abdullah Graduate School of Business, Universiti Utara Malaysia, in fulfillment of the requirement for the Degree of Doctor of Philosophy. Malaysia.

Popoola, O. M. J., Ahmad, A. C., \& Samsudin, R. S. 2013a. Forensic accounting knowledge and skills on task performance fraud risk assessment: Nigerian public sector experience. Conference proceedings. Okinawa, Japan.

Popoola, O. M. J., Ahmad, A. C., Samsudin, R. S., \& Hartini, A. 2013b. Task performance fraud risk assessment on forensic accountant knowledge and mindset in Nigerian public sector. Conference proceedings. Seoul, South Korea.

Preacher, K. J., \& Hayes, A. F. 2008. Asymptotic and resampling strategies for assessing and comparing indirect effects in multiple mediator models. Behavior Research Methods, 40, 879-891.

Ramaswamy, V. 2005. Corporate Governance and the Forensic Accountant. The CPA Journal, v. 75, p. 69-70.

Ramaswamy, V. 2007. New Frontiers: Training Forensic Accountants Within The Accounting Program. Journal of College Teaching \& Learning. September, v.4 (9).

Remenyi, D., Williams, B., Money, A., \& Swartz, E. 1998. Doing research in business and management: An introduction to process and method. London: Sage Publication.

Singleton, T. W., Singleton, A. J., Bologna, G. J., \& Lindquist, R. J. 2006. Fraud Auditing and Forensic Accounting. 3rd Ed. Hoboken, NJ: John Wiley and Sons, Inc.

Stone, M. 1974. Cross-validatory choice and assessment of statistical predictions. Journal of the Royal Statistical Society, 36, 111-147.

Torelli, C. J., \&. Kaikati, A. M. 2009. Values as predictors of judgments and behaviors: The role of abstract and concrete mindsets. Journal of Personality and Social Psychology, 96 (1), 231.

Ugwu, C. (2012). "Nigeria: Court remands two in EFCC custody for alleged N14.6 million fraud. Leadership, November 26.

Wells, J. T. 2005. Accountants need help fighting the war on fraud; ACFE founder urges antifraud Education Press Release]. Retrieved November 13, 2012 from the Association of Certified Fraud Examiner. http://wwwacfe.om/about/press-release.asp?cpy=10-12-2005.

Wuerges, A. 2011. Auditors' Responsibility for Fraud Detection: New Wine in Old Bottles? Retrieved on November 3, 2012 at http://www.scribd.com/doc/63671899/Auditors-Responsibility-for-Fraud-Detection, 
TABLES AND FIGURES

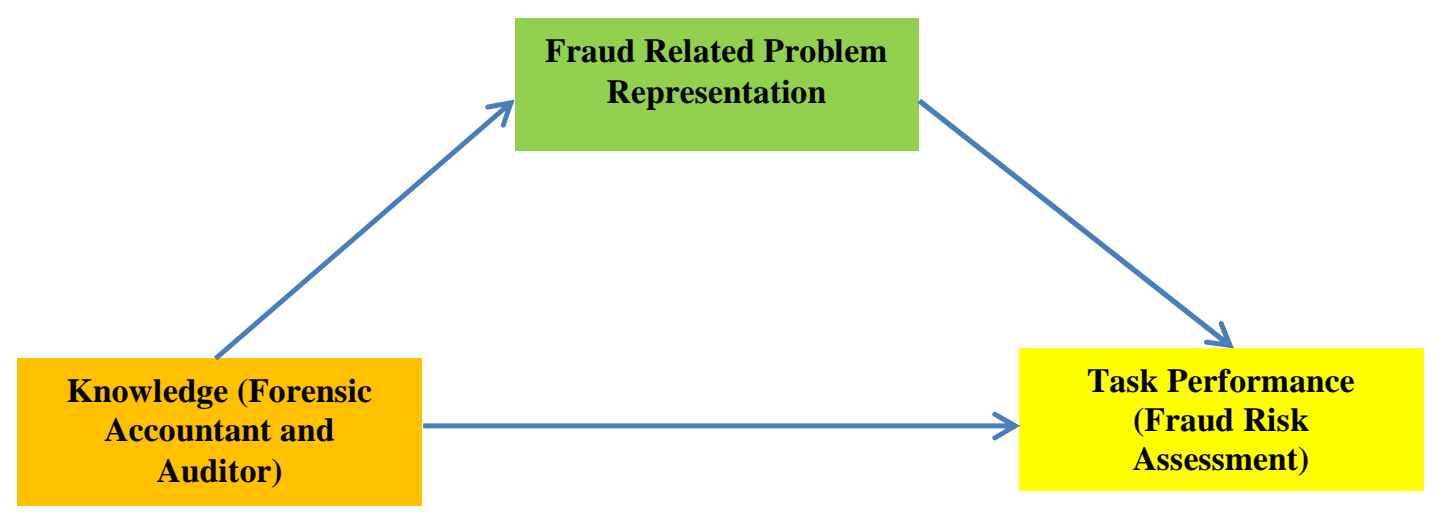

Figure 1 Theoretical Framework: Mediating effect of Fraud Related Problem Representation on Knowledge Requirement and Task Performance Fraud Risk Assessment model

Table 1

Range, Mean and Standard Deviations of Respondents ( $\mathrm{N}=234)$

\begin{tabular}{|lccccc|}
\hline Construct & N & Minimum & Maximum & Mean & Std. Deviation \\
\hline KR & 234 & 3.500 & 5.000 & 4.754 & 0.423 \\
FRPR & 234 & 3.500 & 5.000 & 4.345 & 0.640 \\
TPFRA & 234 & 3.000 & 5.000 & 4.436 & 0.578 \\
\hline
\end{tabular}

Table 2

Key Factor loadings and Cross loadings

\begin{tabular}{|ccccc|}
\hline Latent Variable & Indicators & FRPR & KR & TPFRA \\
\hline & FRPRR13 & $\mathbf{0 . 8 5 4 4}$ & 0.4806 & 0.8091 \\
Fraud Related & FRPRR14 & $\mathbf{0 . 8 8 6 7}$ & 0.6972 & 0.7642 \\
Problem & FRPRR4 & $\mathbf{0 . 7 1 7 3}$ & 0.6216 & 0.6042 \\
Representation & FRPRR5 & $\mathbf{0 . 8 7 8 7}$ & 0.6035 & 0.7224 \\
& FRPRR6 & $\mathbf{0 . 8 0 1 6}$ & 0.45 & 0.707 \\
& FRPRR9 & $\mathbf{0 . 7 8 6 6}$ & 0.3117 & 0.7044 \\
& KR1 & 0.5784 & $\mathbf{0 . 9 3 9 6}$ & 0.4391 \\
Knowledge & KR2 & 0.5476 & $\mathbf{0 . 9 1 8 4}$ & 0.4348 \\
& KR3 & 0.6365 & $\mathbf{0 . 9 2 3 1}$ & 0.4993 \\
& KR4 & 0.5779 & $\mathbf{0 . 8 4 3 8}$ & 0.5364 \\
Task Performance & TPFRAR1 & 0.8088 & 0.4434 & $\mathbf{0 . 9 0 5 6}$ \\
fraud risk & TPFRAR3 & 0.8556 & 0.3984 & $\mathbf{0 . 9 2 0}$ \\
Assessment & TPFRAR4 & 0.7976 & 0.6568 & $\mathbf{0 . 9 0 9}$ \\
& & 0.7615 & 0.4029 & $\mathbf{0 . 8 7 7 8}$ \\
\hline
\end{tabular}


Note: The factor loadings of bold values are greater than the cross loadings of the other construct's values.

Table 3

Model Quality Criteria: Convergent Validity and Reliability Analysis

\begin{tabular}{|c|c|c|c|c|c|c|}
\hline Latent Variable & Indicators & Loadings & $\begin{array}{l}\text { Indicator } \\
\text { Reliability } \\
\end{array}$ & $\begin{array}{l}\text { Composite } \\
\text { Reliability } \\
\end{array}$ & $\mathbf{A V E}^{\mathbf{b}}$ & $\begin{array}{c}\text { Discriminant } \\
\text { Validity? }\end{array}$ \\
\hline \multirow{6}{*}{$\begin{array}{l}\text { Fraud Related Problem } \\
\text { Representation }\end{array}$} & FRPRR13 & 0.854 & 0.729 & \multirow{6}{*}{0.93} & \multirow{6}{*}{0.68} & \multirow{6}{*}{ Yes } \\
\hline & FRPRR14 & 0.887 & 0.787 & & & \\
\hline & FRPRR4 & 0.717 & 0.514 & & & \\
\hline & FRPRR5 & 0.879 & 0.773 & & & \\
\hline & FRPRR6 & 0.802 & 0.643 & & & \\
\hline & FRPRR9 & 0.787 & 0.619 & & & \\
\hline \multirow{4}{*}{ Knowledge } & KR1 & 0.940 & 0.884 & \multirow{4}{*}{0.95} & \multirow{4}{*}{0.82} & \multirow{4}{*}{ Yes } \\
\hline & KR2 & 0.918 & 0.843 & & & \\
\hline & KR3 & 0.923 & 0.852 & & & \\
\hline & KR4 & 0.844 & 0.712 & & & \\
\hline \multirow{4}{*}{$\begin{array}{c}\text { Task Performance Fraud } \\
\text { Risk Assessment }\end{array}$} & TPFRAR1 & 0.906 & 0.821 & \multirow{4}{*}{0.95} & \multirow{4}{*}{0.82} & \multirow{4}{*}{ Yes } \\
\hline & TPFRAR2 & 0.920 & 0.846 & & & \\
\hline & TPFRAR3 & 0.909 & 0.826 & & & \\
\hline & TPFRAR4 & 0.878 & 0.771 & & & \\
\hline
\end{tabular}

Table 4

Correlations and Discriminant Validity

\begin{tabular}{lccc}
\hline \multicolumn{1}{c}{ Constructs } & FRPR & KR & TPFRA \\
\hline Fraud Related Problem Representation & $\mathbf{0 . 8 2 5}$ & & \\
Knowledge & 0.648 & $\mathbf{0 . 9 0 6}$ & \\
Task Performance Fraud Risk Assessment & 0.794 & 0.530 & $\mathbf{0 . 9 0 6}$ \\
\hline
\end{tabular}

Note: Diagonals that displayed in bold represent the squared average variance extracted (AVE) while the values, not in bold represent the correlations. 


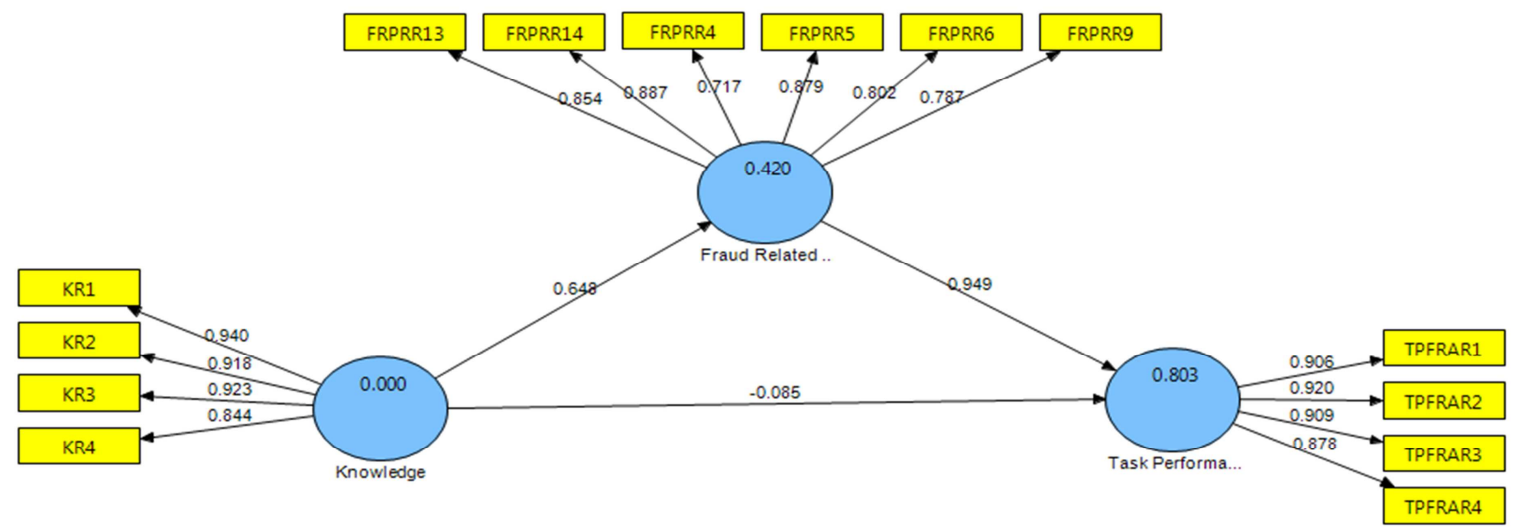

Figure 2: Results of the PLS-SEM Algorithm Direct Effects: KR on TPFRA, KR on FRPR and FRPR on TPFRA

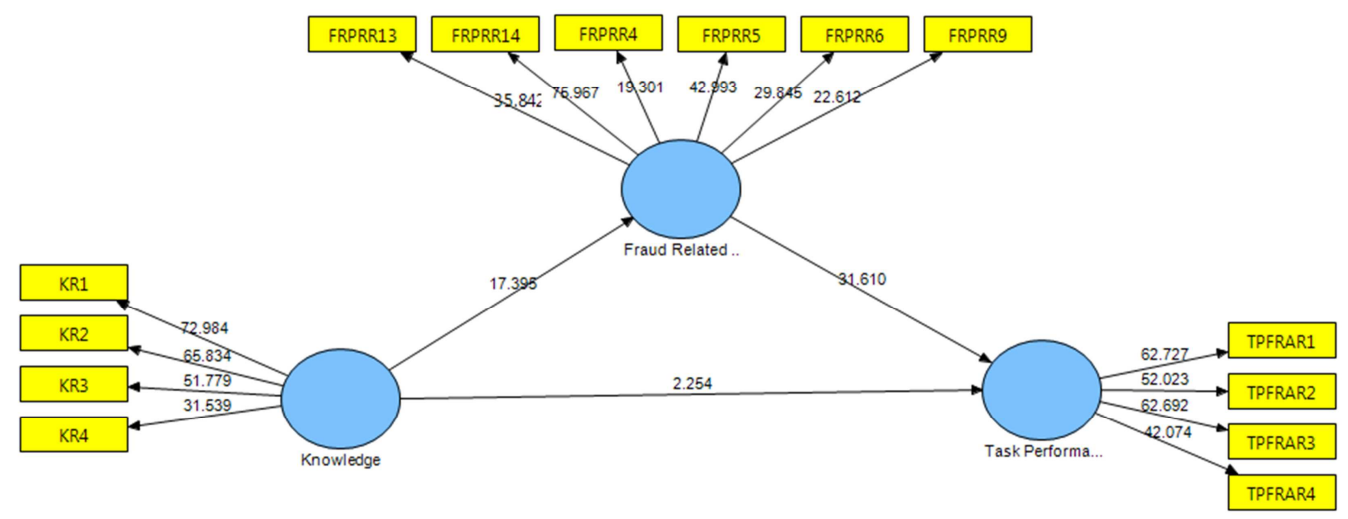

Figure 3

Results of the Bootstrapping Structural Model

Table 5

Assessing $f^{2}$ effect sizes of the Structural Model

\begin{tabular}{cccccc}
\hline \multicolumn{6}{c}{ FRPR } \\
\hline $\begin{array}{c}\text { Endogenous } \\
\text { Construct }\end{array}$ & R2incl & R2excl & R2incl-R2excl & 1-R2incl & Effect Size \\
\hline KR & 0.420 & 0.306 & 0.114 & 0.580 & 0.197
\end{tabular}

Table 6

Assessing the predictive relevance of $Q^{2}$ values in the structural model

TPFRA

\begin{tabular}{cccccc}
\hline $\begin{array}{l}\text { Endogenous } \\
\text { Construct }\end{array}$ & $\mathbf{Q}^{2}$ incl & $\mathbf{Q}^{2}$ excl & $\mathbf{Q}^{2}$ incl-Q & & \\
\hline KRexcl & $\mathbf{1}^{2}$ incl & $\begin{array}{l}\text { Effect } \\
\text { Size }\end{array}$ \\
\hline KR & 0.654 & 0.639 & 0.015 & 0.346 & 0.043 \\
\hline
\end{tabular}


Table 7

Direct relationship effects of KR and FRPR on TPFRA

\begin{tabular}{cccccc}
\hline No & Hypothesis & $\begin{array}{c}\text { Path } \\
\text { Coefficient }\end{array}$ & $\begin{array}{c}\text { Standard } \\
\text { Error }\end{array}$ & T Value & Decision \\
\hline 1 & FRPR $->$ TPFRA & $0.949^{* *}$ & 0.030 & 31.409 & Support \\
2 & KR $->$ FRPR & $0.648^{* *}$ & 0.037 & 17.435 & Support \\
3 & KR $->$ TPFRA & $0.085^{*}$ & 0.038 & 2.238 & Support \\
\hline
\end{tabular}

Note: $* *$ Shows the item is significant at the $\mathrm{p}<0.01(1 \%$ level $)$ and

$*$ indicates the item is significant at $\mathrm{p}<0.05$ ( $5 \%$ level).

\section{Table 8}

PLS-SEM Mediation and Bootstrap of the Indirect Hypothesised path

\begin{tabular}{|c|c|c|c|c|c|c|c|c|c|c|}
\hline \multirow[b]{3}{*}{ No. } & \multirow{3}{*}{ Hypothesis } & \multicolumn{9}{|c|}{ Path Coefficients } \\
\hline & & \multicolumn{2}{|c|}{$\mathbf{a}$} & \multicolumn{2}{|c|}{ b } & \multicolumn{2}{|c|}{ c } & \multicolumn{2}{|c|}{$\mathbf{c}^{\prime}$} & \multirow[b]{2}{*}{$\begin{array}{c}\text { Suppor } \\
\text { ted }\end{array}$} \\
\hline & & $\begin{array}{l}\text { Path } \\
\text { Coef }\end{array}$ & $\begin{array}{c}\mathrm{t}- \\
\text { value }\end{array}$ & $\begin{array}{l}\text { Path } \\
\text { Coef }\end{array}$ & $\begin{array}{c}\mathrm{t}- \\
\text { value }\end{array}$ & $\begin{array}{l}\text { Path } \\
\text { Coef }\end{array}$ & $\begin{array}{c}\text { t- } \\
\text { value }\end{array}$ & $\begin{array}{l}\text { Path } \\
\text { Coef }\end{array}$ & $\begin{array}{c}\mathrm{t}- \\
\text { value }\end{array}$ & \\
\hline 4 & KR --> FRPR-> TPFRA & 0.75 & 16.81 & 0.68 & 13.03 & 0.85 & 22.03 & 0.52 & 9.78 & Yes** \\
\hline
\end{tabular}

Note: $* * \mathrm{p}<.01 ; \mathrm{N}=234,2$-tailed; KR = Knowledge; FRPR = Fraud Related Problem Representation; and TPFRA $=$ Task Performance Fraud Risk Assessment

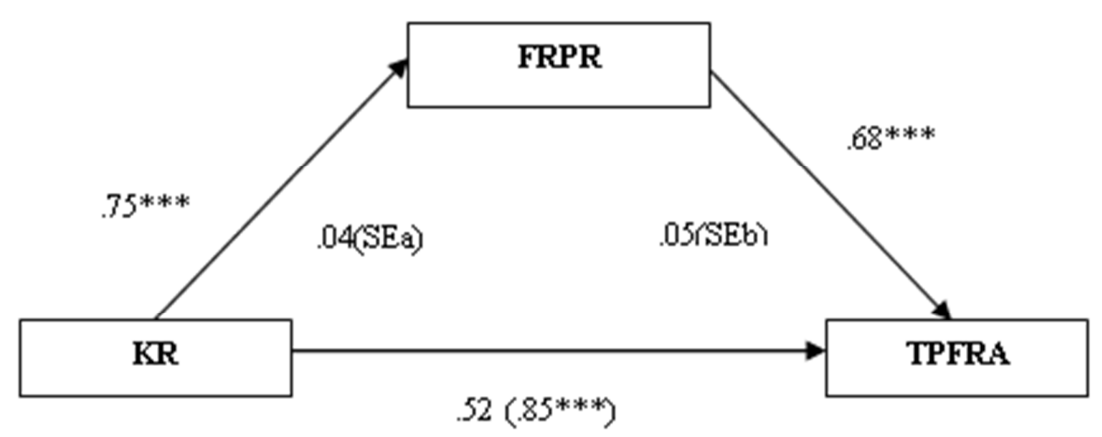

\section{Figure 4}

Mediating Influence of Fraud Related Problem Representation on Knowledge Requirement and Task Performance Fraud Risk Assessment 